TI 2018-039/VIII

Tinbergen Institute Discussion Paper
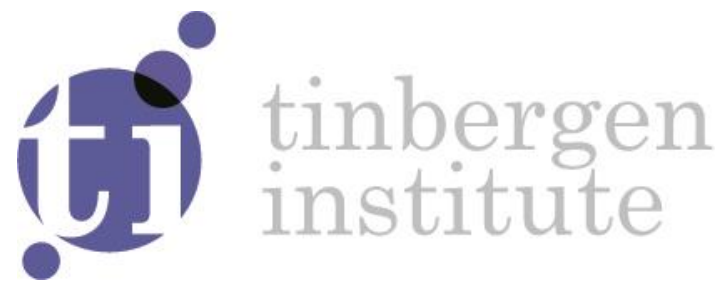

\title{
Economics in the Anthropocene: species extinction or steady state economics
}

\author{
Revision: 4 October 2018
}

Joeri (J.) Sol ${ }^{1}$

\footnotetext{
${ }^{1}$ University of Amsterdam
} 
Tinbergen Institute is the graduate school and research institute in economics of Erasmus University Rotterdam, the University of Amsterdam and VU University Amsterdam.

Contact: discussionpapers@tinbergen.nl

More TI discussion papers can be downloaded at http://www.tinbergen.nl

Tinbergen Institute has two locations:

Tinbergen Institute Amsterdam

Gustav Mahlerplein 117

1082 MS Amsterdam

The Netherlands

Tel.: +31(0)205984580

Tinbergen Institute Rotterdam

Burg. Oudlaan 50

3062 PA Rotterdam

The Netherlands

Tel.: +31(0)10408 8900 
Economics in the Anthropocene: species extinction or steady state economics

Joeri Sol

October $4^{\text {th }}, 2018$

\begin{abstract}
At the dawn of the Anthropocene, continued economic growth carries the risk of irreversibly damaging the global carrying capacity. Using the International Union for the Conservation of Nature Red List of Threatened Species (2016), I calculate expected extinction rates during the coming century for 557 regions. I illustrate that these rates exceed the planetary boundary formulated by Rockström et al. (2009) virtually everywhere and increase with population density and GDP per capita. By doing so, this paper contributes to an ongoing debate whether absolute or relative scarcity is more relevant to economic thought. My findings suggest that the conservation of nature requires degrowth and the transition to a global steady state economy.
\end{abstract}

"I cannot, therefore, regard the stationary state of capital and wealth with the unaffected aversion so generally manifested towards it by political economists of the old school. I am inclined to believe that it would be, on the whole, a very considerable improvement on our present condition."

John S. Mill (1848, Book 4, Chapter 6)

Keywords: Biodiversity, Conservation, Economic growth, IUCN Red List, Population, Steady state economics.

\footnotetext{
*University of Amsterdam, Postbus 15953, 1001 NL Amsterdam, The Netherlands. E-mail: j.sol@uva.nl. I gratefully acknowledge comments and suggestions by Sanjay Bissesur, Josse Delfgaauw, Robert Dur, Henk Simons, and Theodor Vlădășel., as well as by participants at the Economy, Sustainable Development and Energy International Conference in Edinburgh, the First North - South Conference on Degrowth Descrecimiento in Mexico City, and the 15th Congress of the International Society for Ecological Economics in Puebla.
} 


\section{Introduction}

The Anthropocene refers to the geological epoch during which mankind has obtained an influence over global natural processes (Crutzen, 2002). Although the Anthropocene has yet to be formalized by the International Union of Geological Sciences, Waters et al. (2016) argue that humanity's stratigraphic signature is already sufficiently distinct to recognize this geological epoch by reviewing evidence on the growth of new materials (e.g. concrete and plastics) and the transformation of land and ocean surface by mineral extraction and trawler fishing. Wackernagel et al. (2002) estimated that consumption rose from using $70 \%$ of Earth's regenerative capacity in 1961 to $120 \%$ in 1999 , and according to WWF (2016), it currently takes 1.6 Earths to provide for the renewable resources that we lay claim on.

Inspired by the (pending) arrival of the Anthropocene, Rockström et al. (2009) formulate planetary boundaries for economic activity and assign parameter values to eight such ecological limits. Currently, we surpass three safe thresholds: climate change, biodiversity loss, and our influence over the nitrogen cycle. According to Steffen et al. (2015), who propose to add a zone of uncertainty, the latter two boundaries are transgressed beyond doubt. Naturally, the idea that economic growth can only be a transitory stage is not new to economics (Malthus, 1798; Mill, 1848; Boulding, 1966; Georgescu-Roegen, 1971; Meadows et al., 1972). Daly (1974) already reasoned for the desirability and necessity of steady state economics based on common sense and the second law of thermodynamics. The accumulated evidence that continued economic growth could seriously harm global carrying capacity makes a paradigm shift to steady state economics urgent as well. ${ }^{1}$

This paper concentrates on biodiversity loss. Reductions in biodiversity impair global carrying capacity through reduced ecosystem efficiency and resilience, increased risks of infectious diseases, and for many, lower immaterial value. ${ }^{2}$ Background extinction due to

\footnotetext{
1 This paper follows Daly (2013)'s recommendation to distinguish between economic growth and economic development. A steady state economy does not allow for quantitative growth of physical wealth, but does leave room for development, i.e., qualitative improvements in the amount of service obtained from this wealth. Steady state economics should not be confused with the steady state growth paths studied by Solow (1956), unless economic growth in Solow (1956) is interpreted exclusively in terms of development. 2 See, for example, Cardinale et al. (2012, p. 60-61) on ecosystem efficiency: "... as a general rule, reductions in the number of genes, species and functional groups of organisms reduce the efficiency by which whole communities capture biologically essential resources (nutrients, water, light, prey), and convert those resources into biomass." Rockström et al. (2009, p. 474) on ecosystem stability: "Ecosystems that depend on a few or single species for critical functions are vulnerable to disturbances, such as disease,
} 
natural selection is thought to lie between 0.1 and 1 extinctions per million species years (E/MSY), and more likely to be close to 0.1 (Pimm et al., 2014). Rockström et al. (2009) set the planetary boundary for biodiversity loss at $10 \mathrm{E} / \mathrm{MSY}$ and Steffen et al. (2015) add a zone of uncertainty up to $100 \mathrm{E} / \mathrm{MSY}$. The current extinction rate is estimated to lie between 100 and 1000 E/MSY (Pimm et al., 1995; Pimm et al., 2014). Using International Union for the Conservation of Nature (IUCN) Red List of Threatened Species data (2016), and conservative assumptions spelled out in Section 2, I calculate a global expected extinction rate of $759 \mathrm{E} / \mathrm{MSY}$ for the coming century.

This paper contributes by exploring regional variation in expected biodiversity loss across 557 regions, covering about $99 \%$ of the global surface. Although I find large variation in regional expected extinction rates, my findings suggest biodiversity loss is a concern nearly everywhere: only 17 regions stay below the proposed planetary boundary for biodiversity loss and 192 regions have expected extinction rates that can be considered within the zone of uncertainty. The lowest expected extinction rates are found in sparsely populated regions in the Northern hemisphere, while the highest rates are in tropical regions and on islands.

Subsequently, I regress expected extinction rates on both human population density and GDP per capita while controlling for the land surface of the region, for the regions being islands, landlocked, or mega cities, for 11 (sub)continental dummies, and for 3 weather type dummies (that is, deserts, semi-arid and tropical regions). Both population density and GDP per capita show a significant positive association with expected species extinction. Although these partial correlations do not allow for causal inference of an effect of human activity on species extinction, my findings are consistent with the interpretation that economic growth beyond planetary boundaries damages global carrying capacity and that absolute scarcity rather than relative scarcity should be the starting point for economic thought on the conservation of nature. ${ }^{3}$

and at a greater risk of tipping into undesired states." And, Keesing et al. (2010, p. 647) on infectious disease: "... in recent years, a consistent picture has emerged-biodiversity loss tends to increase pathogen transmission and disease incidence." Immaterial value is also referred to as intrinsic value or existence value. Finally, see Chapin et al. (2000) and Costanza et al. (1997) for examples of the importance of biodiversity for ecosystem services and the valuation of these services, respectively.

${ }^{3}$ See Baumgärtner et al (2006) for a review of both scarcity concepts in relation to biodiversity loss. 
This paper proceeds as follows: Section 2 describes the data, Section 3 contains the analysis, Section 4 presents a discussion of the results and Section 5 concludes.

\section{Data}

The IUCN Red List of Threatened Species contains assessments of extinction threat levels for both plant and animal species based on population size, habitat range, and estimated extinction risk. This paper uses the 2016-2 version that contains 82,954 assessments, categorized as either least concern $(39,053)$, data deficient $(13,489)$, vulnerable $(11,219)$, endangered $(7,602)$, near threatened $(5,323)$, critically endangered $(5,107)$, extinct $(855)$, lower risk/conservation dependent $(238)$, or extinct in the wild $(68)$. Most of the assessments are carried out by the IUCN Species Survival Commission, and all assessment are reviewed by a member from the Red List Authority on the relevant taxonomic group. Close to 70 percent of species has been (re)assessed after 2010 .

To construct my dependent variable, Extinction rate, I assume that the elevated extinction risk criterion - which is one out of five sufficiency criteria for the assessment categories vulnerable, endangered and critically endangered - is a valid estimate for the extinction risk of each assessment within the category. ${ }^{4}$ For critically endangered species, the extinction risk criterion specifies a probability of extinction of at least $50 \%$ during the coming 10 years, and for endangered and vulnerable species $20 \%$ and $10 \%$ within 20 and 100 years, respectively (IUCN, 2012). I use these probabilities to calculate the number of expect extinctions during the coming century and add the expected background extinctions by multiplying the number of non-extinct non-data deficient species with the upper bound estimate for background extinction from Rockström et al. (2009) of $1 \mathrm{E} / \mathrm{MSY} .^{5}$ Finally, I express this estimate for expected extinctions relative to

\footnotetext{
${ }^{4}$ On the hand, one can argue that this assumption leads underestimation of the extinction rate, as it is a sufficiency criterion. On the other hand, it is only one out of five sufficiency criteria, allowing for overestimation of the extinction rate. Other sufficiency conditions specify population size, changes to population size and habitat ranges; for example, a "population size estimated to number fewer than 50 mature individuals" gives the assessment critically endangered (IUCN 2012, p.9). See IUCN (2012) for the complete description of the sufficiency criteria. Section 4 also addresses the practice of turning assessment categories into extinction probabilities and some robustness checks.

5 I further assume that (critically) endangered species that managed to survive (ten) twenty years will continue to do so for the remainder of the century. Assuming that (critically) endangered species that survive (ten) twenty years face an unchanged extinction risk, would more than double the global extinction
} 
the background extinctions. Under these assumptions, Extinction rate ranges from 1 (i.e., no species has an elevated extinction risk) to 5001 (i.e., all species are critically endangered). Globally, the expected extinction rate is 759 times the background extinction rate, or slightly over $15 \%$ of its theoretical maximum. ${ }^{6}$ The proposed planetary boundary is 10 times background extinction, and the zone of uncertainty ends at 100 times the background rate.

To calculate the regional estimates, I only consider the assessments of species that were labelled as once native to the region. Although I refer to regional estimates, I base my estimates on global extinction risk; for example, the Giant Panda which is assessed as vulnerable and regionally extinct in Hunan, contributes to the extinction rate of Hunan, because it is labelled as once native to the region. ${ }^{7}$ Figure 1 presents the geographical distribution of Extinction rate for 538 terrestrial regions and 19 oceanic regions, covering about $99 \%$ of global surface.

Figure 1 depicts regions that stay below the planetary boundary for biodiversity loss in a dark green color (17 regions, representing 2.6 percent of assessed land surface) and those that stay within in the zone of uncertainty in light green and yellow (192 regions, making up 46.2 percent of assessed land surface). ${ }^{8}$ Due to the positive skew in the regional estimates, illustrated in Figure 2, I chose different bin sizes for the colors used in Figure 1; apart from the consideration that the extinction rates should be comparable within color category and the intention to illustrate the variation in extinction rates, the other cut-off levels are arbitrary. In the regression analysis, I use Ln Extinction rate as my dependent variable due to the earlier mentioned skew.

rate estimate. This alternative assumption also implies that less than one in thousand critically endangered species can be expected to survive the century.

6 This estimate of 759 consists of the expected extinctions due to heightened extinction risk $(5,195.8=$ $\left.0.5^{\star} 5,107+0.2^{*} 7,602+0.1^{*} 11,219\right)$ plus background extinctions $\left(6.852=1^{*}(82,954-855-86-13,489)^{*}\right.$ $100 / 1,000,000)$ relative to the background extinctions. Using the lower bound for background extinction gives an expected rate of 7,584 times the background rate and planetary boundary of 100 times the background rate. In the remainder of the paper, I discuss the estimates relative to the upper bound.

${ }^{7}$ Cardillo et al. (2005) find little relation between human population density and the extinction risk of large mammal species and suggest that the most vulnerable species have already disappeared from populous regions; calculating extinction rates over species that were once native to the region preempts this.

8 In case I was unable to determine whether an area was assessed, or uncertain about the area to which an IUCN location label referred, I left the area blank. Note that, all oceanic regions exceed the planetary boundary for biodiversity loss beyond doubt. These $19 \mathrm{FAO}$ marine regions are not included in the analysis and left undiscussed except for footnote 11 and Appendix B. 
Table 1 presents the number of observations, mean, and standard deviation for Extinction rate along with Population density, GDP per capita, Land surface, Species assessed, Data deficient species, and their correlations. For population density, GDP per capita and land surface, I used 2015 estimates from the World Bank for most countries, complemented with regional estimates from various sources. ${ }^{9}$ These variables exhibit a large positive skew as well, hence I use their logged values in the regression analysis. The number of observations drops to 508 , due to the omission of uninhabited regions and regions for which I did not find information on GDP per capita.

The difference between the regional mean (192) and global extinction rate (759) may be surprising at first, however this difference is expected when (critically) endangered species have smaller habitats; in other words, species without an elevated extinction risk occur in several regional estimates, but only once in the global estimate. For this reason, all regressions control for land surface. Inspection of Figure 1 and 2 reveals that part of the variation may be attributed to regions being coastal, landlocked or islands, where landlocked regions have lower extinction rates and islands have higher rates. Similarly, Figure 1 shows notable (sub)continental variation, possibly related to the type of ecosystems. In the regression analysis, I add 17 dummies to control for the regions' type, location and weather. ${ }^{10}$

\footnotetext{
9 The additional sources include data from the United Nations, the CIA World Factbook, Eurostat and various national statistics agencies; that is, for Argentina (23 regions), Australia (8 regions), Brazil (27 regions), Canada (13 regions), Chile (12 regions), China (31 regions), India (31 regions), Indonesia (7 regions), Japan (5 regions), Mexico (32 regions), Russia (21 regions), South Africa (9 regions), and the United States (50 regions). In the regression analysis, I cluster standard errors on the (sub-)continental and national level to address possible differences in measurement between these agencies. Appendix A provides more detail on the omitted regions and additional sources.

10 In the regression analysis I introduce 11 (sub)continental dummy variables for Caribbean (28 regions), East Asia (42 regions), Europe (45 regions), Mesoamerica (39 regions), North Africa (7 regions), North America (64 regions), North Asia (26 regions), Oceania (38 regions), South and Southeast Asia (55 regions), Sub Saharan Africa (61 regions), West and Central Asia (27 regions), where the 76 regions in South America serve as the base category. I followed IUCN's division of (sub)continental areas, except for the Canary Islands and Madeira (relabeled as North African regions instead of European) and Hawaii (relabeled to belong to Oceania instead of North America). I add two dummy variables landlocked (172 regions) and island (117 regions), where the 219 coastal regions serve as the base category. I add a dummy for city states (11 regions); the results are robust to the exclusion of these regions (and even slightly more pronounced). Finally, I created three dummies based on average annual precipitation in region's capital: that is, deserts ( 35 regions, $<250 \mathrm{~mm}$ ), semi-arid ( 65 regions, $250 \mathrm{~mm}$ to $500 \mathrm{~mm}$ ) and tropical ( 30 regions, $>2500 \mathrm{~mm}$ ). The weather information was obtained through Wikipedia pages that link to several meteorological websites, and due to possible lower reliability, added separately in the regression analysis. The results in Table 2 are robust to the exclusion of these weather dummies, although Ln GDP per cap is only significant at the $10 \%$ level after the clustering of standard errors in (3).
} 


\section{Analysis}

I regress the logged values of Extinction rate on the logged values of Population density and GDP per capita using Ordinary Least Squares, giving the following regression equation:

Ln Extinction rate ${ }_{i}=\beta_{0}+\beta_{1}$ Ln Population density $_{i}+\beta_{2}$ Ln GDP per capita ${ }_{i}+\sum_{j=3}^{19} \beta_{j}$ Control $_{j i}+\varepsilon_{i}$,

where $i$ refers to the region and $j$ to the earlier discussed controls. Under the null hypothesis, supposing that absolute scarcity is irrelevant, one may expect $\beta_{1} \leq 0$ and $\beta_{2} \leq$ 0 ; that is, regional population density and GDP per capita are either unrelated to extinction rates or negatively related (e.g. when more prosperous regions have more means for conservation or outsource their polluting activities). ${ }^{11}$ The alternative hypothesis, $\beta_{1}>0$ and $\beta_{2}>0$, is consistent with absolute scarcity being relevant; more densely populated regions and regions with more economic activity are associated with higher extinction rates. Table 2 presents the estimates of equation (1) using the region type controls in column (1) and with weather type controls added in column (2). In column (3), I cluster standard errors on the (sub)continental and national level, as detailed in footnote 9 .

Table 2 shows that both population density and GDP per capita are positively associated with extinction rates, and statistically significant at the 1 percent level (also jointly, as illustrated by the F-statistics). Column (1) of Table 2 shows that a doubling of population density and a doubling of GDP per capita are associated with an increase in the extinction rate of a little over 13 percent and close to 15 percent, respectively. Controlling for the weather type of the region in column (2) hardly changes the estimated coefficient of population density and increases the estimate for GDP per capita to 17 percent per doubling. Clustering the standard errors on 24 (sub)continental and national clusters in column (3) reduces the significance for GDP per capita slightly ( $p$-value $=0.031$ ). To put these estimates in perspective, a 15 percent higher extinction rate would give 785

\footnotetext{
11 The (sub)continental controls partially address this issue; that is, the coefficients for population density and GDP per capita are estimated on within (sub)continental variation of extinction rates, so possible differences due to international trade between the global North and South would be captured by these (sub)continental controls. Appendix B presents a scatterplot of Ln Extinction rate and Ln Population density for (sub)continental and FAO marine regions suggesting that a positive relation may also present at the (sub)continental and oceanic level, but not for Ln GDP per capita. Note that, even though I specified onetailed hypotheses, the $p$-values throughout the paper refer to two-tailed tests.
} 
additional expected extinctions during the coming century, almost equal to the number of recorded extinctions during the past millennium. ${ }^{12}$

Although partial correlations do not allow for causal inference of an effect of human activity on species extinction, it is difficult to think of other explanations. ${ }^{13}$ One such alternative explanation could be that the assessment process rather than absolute scarcity explains the earlier shown relations. If endangered species are more difficult to assess for researchers in more sparsely populated regions or researchers in richer regions have more means to make such assessments, extinction rates may vary with assessment effort. While there does seem to be some merit to this alternative explanation, controlling for the number of species assessed and the number of data deficient species does not change the results qualitatively. ${ }^{14}$

\section{Discussion}

Although the practice of turning assessment categories into extinction probabilities is not undebated (e.g. rankings that combine assessment categories are sensitive to the chosen weights), Mooers et al. (2009, p. 3700) describe that: "The Red List is currently the only basis we know of for consistent, broadly-available estimates of extinction risk, and indeed was originally formulated to be consistent with (at least) notional probabilities of extinction." 15 Likewise, the partial correlations that I present are meant to demonstrate limits to growth rather than present precise point estimates of how population density and

\footnotetext{
12 The global extinction rate would be raised from 759 to 873 , or 114 times the background extinction of 6.9 species, and some of the 855 extinctions date back from the 11th century (e.g., the Madagascan Dwarf Hippopotamus). If anything, I expect my estimates to suffer from a downward attenuation bias due to regional spillovers.

13 Dirzo et al. (2014) uses an earlier version of the IUCN Red List to illustrate that the body mass of extinct fauna is larger than that of threatened fauna, which in turn is much larger than non-threatened fauna; a pattern consistent with a human influence.

${ }^{14}$ Appendix $\mathrm{C}$ show that some of the control variables change more dramatically upon the inclusion of the number of species assessed and the number of data deficient species; e.g., the landlocked dummy is no longer significantly related to extinction rates, while the South and Southeast Asia dummy turns significant. The clustering of standard errors in (4) gives p-values of .025 and .043 for Ln Population density and $L n$ GDP per capita, respectively, while Ln Species assessed and Ln Data deficient are not robust to clustering with p-values of .384 and .092 .

15 On top, Extinction rate is sensitive to the chosen timespan. For example, calculating the extinction rate for the coming two decades based on critically endangered species and endangered species only (while leaving other assumptions spelled out in Section 2 unchanged), raises the theoretical maximum Extinction rate to 25,001 . Using an alternative method, based on simulations of species abundance and habitat size relations, Pimm and Raven (2000) estimate extinction rates ranging between 3,000 E/MSY to almost 50,000 E/MSY for the coming century.
} 
GDP per capita contribute to species extinction. That said, the results are robust to using the assessment categories as dependent variables: replacing Extinction rate in column (4) of Table 2 with the percentage of critically endangered species, the percentage of critically endangered and endangered species, or the percentage of (critically) endangered and vulnerable species gives standardized coefficients of roughly the same size.${ }^{16}$ Moreover, Extinction rate is related closely to the Red List Index used in Hoffman et al. (2010) and Rodriguez et al. (2014), with the advantage of facilitating interpretation in terms of the planetary boundary concept. ${ }^{17}$

While I do consider the regional variation in Extinction rate that I illustrate in this paper informative, I caution the reader to base conservation priorities solely on these rates. In terms of the library metaphor in Weitzman (1998)'s Noah's Ark problem, the expected extinction rates could be considered the state of a library, but not the number of books in the library (i.e., species richness) nor their distinctiveness (i.e., species' isolation on a phylogenetic tree). ${ }^{18}$ For maps of species richness and genetic diversity, see Grenyer et al. (2006) and Miraldo et al. (2014), respectively, and Rodriguez et al. (2014) presents maps for changes in the Red List Index and dominant threats to endangered species. ${ }^{19}$

So far, this paper has ignored the information on the type of threats provided with the IUCN assessments. Some of the main threats (biological resource use, agri- and aquaculture, and residential and commercial development) could be remedied against by protecting sufficiently large habitats. Unfortunately, most nations still fail to meet the 2020

\footnotetext{
16 For Population density, the standardized coefficients (and p-values) are $.158(.014), .267$ (<.001), and .213 (<.001), respectively, while for GDP per capita I find .209 (.001), .222 (<.001), and .127 (.021). Using Tobit regressions instead of OLS, raises the estimated coefficients a little and reduces the $p$-values; the results are available upon request.

17 The Red List Index (RLI), as defined in Butchart et al. (2007), ranges from zero to one, where zero refers to all species being extinct and one to all species being categorized as least concern. My Extinction rate measure can be translated into the RLI without the extinct categories: If, instead, we define RLIx only over extant species and refer to zero as all species being critically endangered, then $\mathrm{RLI}^{\mathrm{x}}=(5001-$ Extinction rate) / 5000.

18 Weitzman (1998) models a policymaker (Noah) that maximizes biodiversity subject to a limited conservation budget (the Ark). Recent extensions to this seminal model illustrate that introducing species interactions (Courtois et al., 2014) or allowing for uncertainty about future states of the world (Perry and Shankar, 2017) changes the distribution of the conservation budget; e.g. towards prey instead of predators or towards keystone species, respectively. In a different approach, Conrad (2018) applies real option theory to determine at what population size policymakers should initiate conservation measures.

19 To be more precise, Grenyer et al. (2006) maps the species richness of vertebrates, see Joppa et al. (2013) for endemic plants. Hoffman et al. (2010) find that on average 52 species per year move one Red List category closer to extinction and estimate that this trend would have been at least 20 percent worse without conservation efforts.
} 
Aichi Biodiversity Targets for legally protected areas, set at 17 and 10 percent of land surface and territorial waters, respectively (CBD, 2010). ${ }^{20}$ Moreover, protected areas are biased towards locations where they prevent little land conversion (Joppa and Pfaff, 2009) and are often undervalued (Watson et al., 2014). However, it is unlikely that economic growth will help to close the gaps in conservation budgets; that is, I find little evidence in favor of an Environmental Kuznets Curve for expected extinction rates. ${ }^{21}$ More emphatically, the estimated shortfall of the global conservation budget seems rather modest: McCarthy et al. (2012, p. 4) find that: "the total required is less than $20 \%$ of annual global consumer spending on soft drinks."

\section{Conclusion}

The analysis of IUCN Red List assessments presented in this paper reveals that expected biodiversity loss is surpassing safe thresholds virtually everywhere and that species extinction is increasing with population density and GDP per capita. This association between the rate of species extinction and human activity is unlikely to be the result of the assessment process, suggesting that the conservation of nature would benefit from degrowth or the transition to a steady state economy.

Serious action to preserve biodiversity, considered a moral obligation by many, requires institutional changes that go beyond the establishment of protected areas: for example, climate change is closely related to species extinction (Pounds et al., 2006; Frieler et al., 2013), putting constraints on the collective consumption of fossil fuels (McGlade and Ekins, 2015). Victor (2008) explores policy mixes that enable the transition to a steady state economy and presents simulations of such a transition for Canada, showing that it allows for lower greenhouse gas emissions, less poverty, more leisure and fiscal balance. In short, economic policy in the Anthropocene should aim to improve carrying capacity rather than zealously chase economic growth.

20 Data from the World Bank shows that 95 out of 213 countries met the target for protection on land in 2017 , and 43 out of 176 countries did so for marine areas.

${ }^{21}$ While adding $L n$ GDP per capita squared does give a negative coefficient ( $p$-value .078 ), the predicted turning point is at the $95^{\text {th }}$ percentile of highest income and I find no evidence for the downward-sloping part of the EKC: adding Ln GDP per capita interacted with dummies for the top quartile, decile or top 5 percent of GDP per capita gives insignificant results. Moreover, Mills and Waite (2009) show that initial evidence of an EKC for deforestation can be spurious when addressing issues of heteroskedasticity and autocorrelation. 


\section{References}

Baumgärtner, S., Becker, C., Faber, M., and Manstetten, R., 2006. "Relative and absolute scarcity of nature. Assessing the roles of economics and ecology for biodiversity conservation." Ecological Economics, 59(4), 487.

Boulding, K.E., 1966. The Economics of the Coming Spaceship Earth. in: Environmental Quality Issues in a Growing Economy, ed. Daly, H. E., Johns Hopkins University Press.

Butchart, S.H., Akçakaya, H.R., Chanson, J., Baillie, J.E., Collen, B., Quader, S., Turner, W.R., Amin, R., Stuart, S.N. and Hilton-Taylor, C., 2007. Improvements to the red list index. PloS one, 2(1): p.e140.

Cardillo, M., Mace, G.M., Jones, K.E., Bielby, J., Bininda-Emonds, O.R., Sechrest, W., Orme, C.D.L. and Purvis, A., 2005. Multiple causes of high extinction risk in large mammal species. Science, 309(5738): 1239-1241.

Cardinale, B.J., Duffy, J.E., Gonzalez, A., Hooper, D.U., Perrings, C., Venail, P., Narwani, A., Mace, G.M., Tilman, D., Wardle, D.A. and Kinzig, A.P., 2012. Biodiversity loss and its impact on humanity. Nature, 486(7401), p.59.

CBD, 2010. The Strategic Plan for Biodiversity 2011-2020 and the Aichi Biodiversity Targets. Convention on Biological Diversity, Nagoya, Japan. 18-29 October 2010.

Chapin lii, F.S., Zavaleta, E.S., Eviner, V.T., Naylor, R.L., Vitousek, P.M., Reynolds, H.L., Hooper, D.U., Lavorel, S., Sala, O.E., Hobbie, S.E. and Mack, M.C., 2000. Consequences of changing biodiversity. Nature, 405(6783), p.234.

Conrad, J.M., 2018. Real Options for Endangered Species. Ecological Economics, 144, pp.59-64.

Costanza, R., d'Arge, R., De Groot, R., Farber, S., Grasso, M., Hannon, B., Limburg, K., Naeem, S., O'neill, R.V., Paruelo, J. and Raskin, R.G., 1997. The value of the world's ecosystem services and natural capital. nature, 387(6630), p.253.

Courtois, P., Figuieres, C. and Mulier, C., 2014. Conservation priorities when species interact: the Noah's ark metaphor revisited. PloS one, 9(9), p.e106073. 
Crutzen, P.J., 2002. Geology of mankind. Nature, 415(6867), p.23.

Daly, H.E., 1974. The economics of the steady state. The American Economic Review, 64(2), pp.15-21.

Daly, H., 2013. A further critique of growth economics. Ecological Economics, 88, pp.2024.

Dirzo, R., Young, H.S., Galetti, M., Ceballos, G., Isaac, N.J. and Collen, B., 2014. Defaunation in the Anthropocene. Science, 345(6195), pp.401-406.

Frieler, K., Meinshausen, M., Golly, A., Mengel, M., Lebek, K., Donner, S.D. and HoeghGuldberg, O., 2013. Limiting global warming to $2 \mathrm{C}$ is unlikely to save most coral reefs. Nature Climate Change, 3(2), p.165.

Georgescu-Roegen, N., 1971. The Entropy Law and the Economic Process. Cambridge: Harvard University Press.

Grenyer, R., Orme, C.D.L., Jackson, S.F., Thomas, G.H., Davies, R.G., Davies, T.J., Jones, K.E., Olson, V.A., Ridgely, R.S., Rasmussen, P.C. and Ding, T.S., 2006. Global distribution and conservation of rare and threatened vertebrates. Nature, 444(7115), p.93. Hoffmann, M., Hilton-Taylor, C., Angulo, A., Böhm, M., Brooks, T.M., Butchart, S.H., Carpenter, K.E., Chanson, J., Collen, B., Cox, N.A. and Darwall, W.R., 2010. The impact of conservation on the status of the world's vertebrates. Science, p.1194442.

IUCN, 2012. IUCN Red List Categories and Criteria: Version 3.1. IUCN Species Survival Commission, Gland, Switzerland.

IUCN, 2016. Red List of Threatened Species, Second Version, iucnredlist.org/search.

Joppa, L.N. and Pfaff, A., 2009. High and far: biases in the location of protected areas. PloS one, 4(12), p.e8273.

Joppa, L.N., Visconti, P., Jenkins, C.N. and Pimm, S.L., 2013. Achieving the convention on biological diversity's goals for plant conservation. Science, 341(6150), pp.1100-1103. 
Keesing, F., Belden, L.K., Daszak, P., Dobson, A., Harvell, C.D., Holt, R.D., Hudson, P., Jolles, A., Jones, K.E., Mitchell, C.E. and Myers, S.S., 2010. Impacts of biodiversity on the emergence and transmission of infectious diseases. Nature, 468(7324), p.647.

Malthus, T. R., 1798. An essay on the principle of population. Oxford: Oxford University Press.

McCarthy, D.P., Donald, P.F., Scharlemann, J.P., Buchanan, G.M., Balmford, A., Green, J.M., Bennun, L.A., Burgess, N.D., Fishpool, L.D., Garnett, S.T. and Leonard, D.L., 2012. Financial costs of meeting global biodiversity conservation targets: current spending and unmet needs. Science, p.1229803.

McGlade, C. and Ekins, P., 2015. The geographical distribution of fossil fuels unused when limiting global warming to $2 \mathrm{C}$. Nature, 517(7533), p.187.

Meadows, D. H., Meadows, D. L., Randers, J., \& Behrens, W. W., 1972. The limits to growth. New York: Universe.

Mill, J. S., 1848. Principles of political economy with some of their applications to social philosophy, London: JW Parker.

Mills, J.H. and Waite, T.A., 2009. Economic prosperity, biodiversity conservation, and the environmental Kuznets curve. Ecological Economics, 68(7), pp.2087-2095.

Miraldo, A., Li, S., Borregaard, M.K., Flórez-Rodríguez, A., Gopalakrishnan, S., Rizvanovic, M., Wang, Z., Rahbek, C., Marske, K.A. and Nogués-Bravo, D., 2016. An Anthropocene map of genetic diversity. Science, 353(6307), pp.1532-1535.

Mooers, A.Ø., Faith, D.P. and Maddison, W.P., 2008. Converting endangered species categories to probabilities of extinction for phylogenetic conservation prioritization. PloS one, 3(11), p.e3700.

Perry, N. and Shankar, S., 2017. The State-contingent Approach to the Noah's Ark Problem. Ecological Economics, 134, pp.65-72. 
Pimm, S.L., Jenkins, C.N., Abell, R., Brooks, T.M., Gittleman, J.L., Joppa, L.N., Raven, P.H., Roberts, C.M. and Sexton, J.O., 2014. The biodiversity of species and their rates of extinction, distribution, and protection. Science, 344(6187), p.1246752.

Pimm, S.L. and Raven, P., 2000. Biodiversity: extinction by numbers. Nature, 403(6772), p.843.

Pimm, S.L., Russell, G.J., Gittleman, J.L. and Brooks, T.M., 1995. The future of biodiversity. Science, 269(5222), pp.347-350.

Pounds, J.A., Bustamante, M.R., Coloma, L.A., Consuegra, J.A., Fogden, M.P., Foster, P.N., La Marca, E., Masters, K.L., Merino-Viteri, A., Puschendorf, R. and Ron, S.R., 2006. Widespread amphibian extinctions from epidemic disease driven by global warming. Nature, 439(7073), p.161.

Rockström, J., Steffen, W., Noone, K., Persson, Å., Chapin III, F.S., Lambin, E.F., Lenton, T.M., Scheffer, M., Folke, C., Schellnhuber, H.J. and Nykvist, B., 2009. A safe operating space for humanity. Nature, 461(7263), p.472.

Rodrigues, A.S., Brooks, T.M., Butchart, S.H., Chanson, J., Cox, N., Hoffmann, M. and Stuart, S.N., 2014. Spatially explicit trends in the global conservation status of vertebrates. PLoS One, 9(11), p.e113934.

Solow, R.M., 1956. A contribution to the theory of economic growth. The Quarterly Journal of Economics, 70(1), pp.65-94.

Steffen, W., Richardson, K., Rockström, J., Cornell, S.E., Fetzer, I., Bennett, E.M., Biggs, R., Carpenter, S.R., De Vries, W., De Wit, C.A. and Folke, C., 2015. Planetary boundaries: Guiding human development on a changing planet. Science, 347(6223), p.1259855.

Victor, P.A., 2008. Managing without growth: slower by design, not disaster. Edward Elgar Publishing.

Wackernagel, M., Schulz, N.B., Deumling, D., Linares, A.C., Jenkins, M., Kapos, V., Monfreda, C., Loh, J., Myers, N., Norgaard, R. and Randers, J., 2002. Tracking the 
ecological overshoot of the human economy. Proceedings of the national Academy of Sciences, 99(14), pp.9266-9271.

Waters, C.N., Zalasiewicz, J., Summerhayes, C., Barnosky, A.D., Poirier, C., Gałuszka, A., Cearreta, A., Edgeworth, M., Ellis, E.C., Ellis, M. and Jeandel, C., 2016. The Anthropocene is functionally and stratigraphically distinct from the Holocene. Science, 351(6269), p.aad2622.

Watson, J.E., Dudley, N., Segan, D.B. and Hockings, M., 2014. The performance and potential of protected areas. Nature, 515(7525), p.67.

Weitzman, M.L., 1998. The Noah's ark problem. Econometrica, pp.1279-1298.

WWF, 2016. Living Planet: Report 2016: Risk and Resilience in a New Era. World Wide Fund for nature, Gland, Switzerland. 


\section{Figures and Tables}

Figure 1: Geographical distribution of Extinction rate.

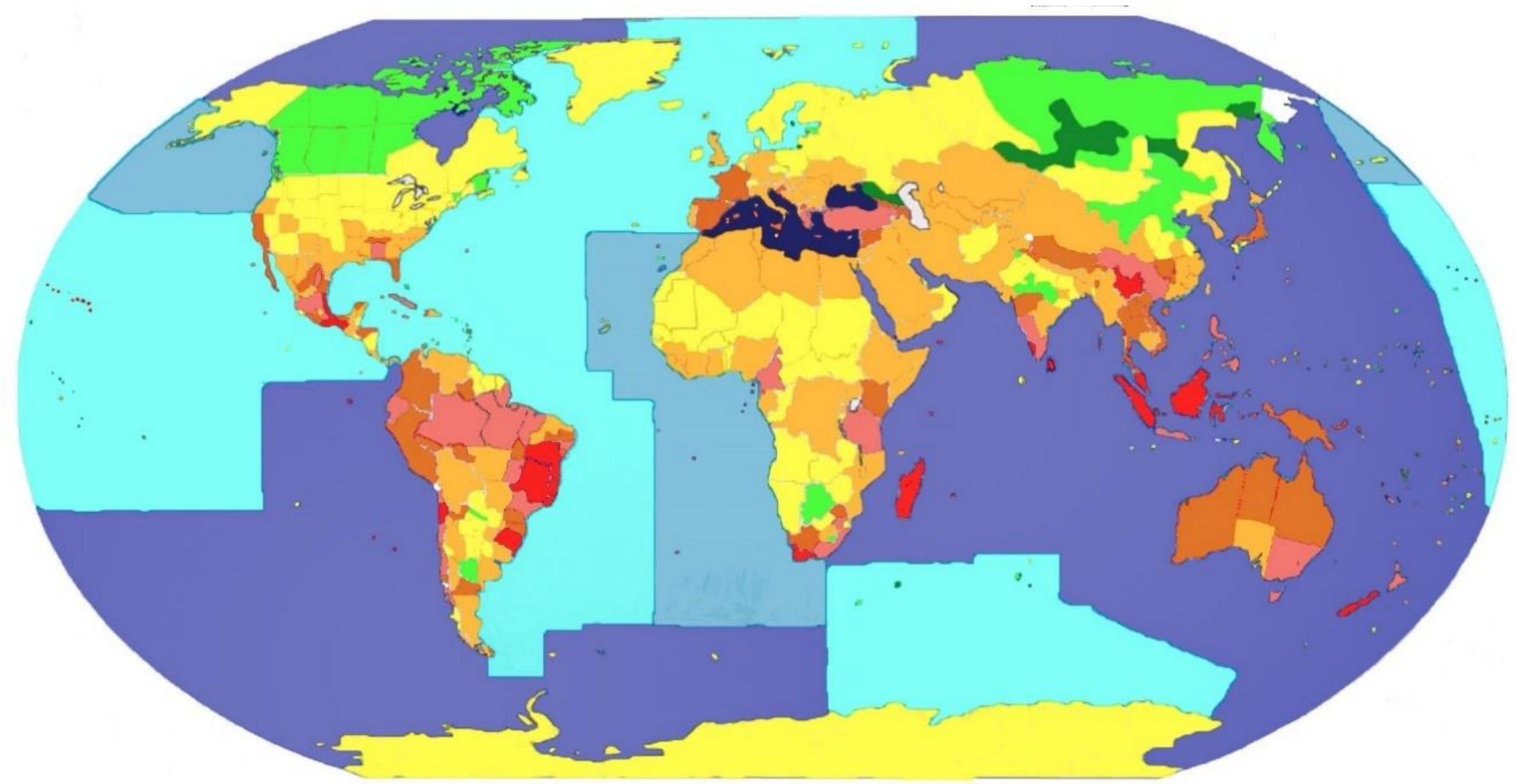

Expected extinction rates for the coming century relative to background extinction

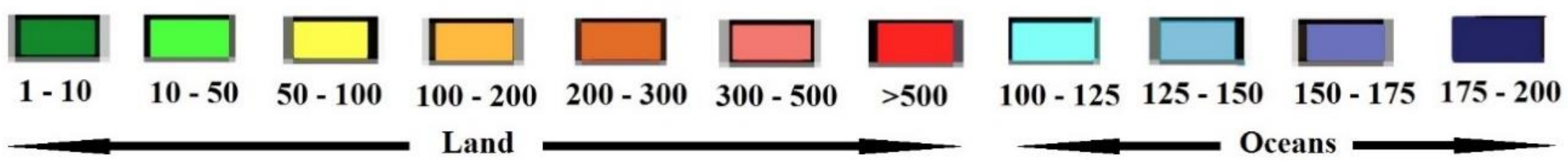


Figure 2: Distribution of Extinction rate by region type.
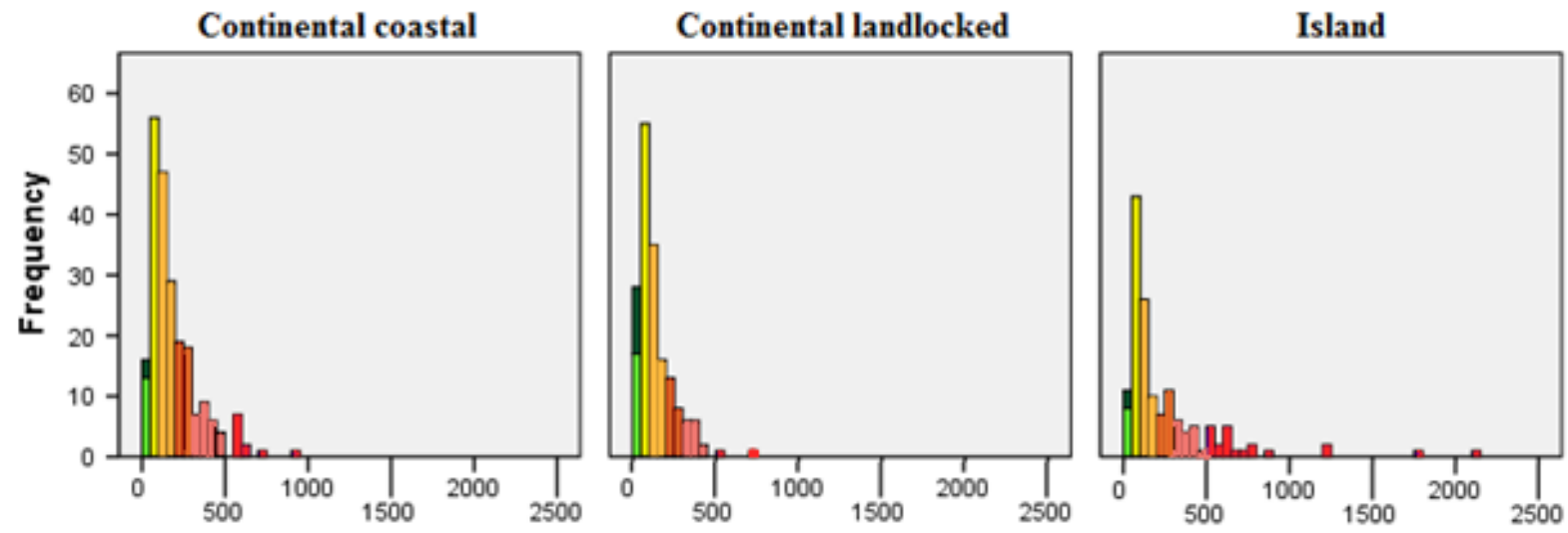

Extinction Rate

Table 1: Descriptive statistics and correlations.

\begin{tabular}{lccc|ccccc} 
& $\mathrm{N}$ & Mean & SD & (2) & (3) & (4) & (5) & \multicolumn{1}{c}{$(6)$} \\
\hline (1) Extinction rate & 508 & 191.7 & 200.8 & -.02 & $-.10^{* *}$ & $-.09^{* *}$ & .01 & $.14^{* * *}$ \\
(2) Population density & 508 & 270.4 & 1178.3 & & $.20^{* * *}$ & $-.10^{* *}$ & -.04 & -.02 \\
(3) GDP per capita & 508 & 20.7 & 19.5 & & & .03 & $-.11^{* *}$ & $-.13^{* * *}$ \\
(4) Land surface & 508 & 256.4 & 466.4 & & & & $.20^{* * *}$ & $.19^{* * *}$ \\
(5) Species assessed & 508 & 876.2 & 969.9 & & & & & $.90^{* * *}$ \\
(6) Data deficient species & 508 & 60.1 & 86.9 & & & & & \\
${ }^{* * *},{ }^{* *},{ }^{*}$ indicate correlations significantly different from zero at the $1 \%, 5 \%$, and $10 \%$. & & &
\end{tabular}

(1) in expected extinctions per background extinctions, (2) in inhabitant per square kilometer, (3) in 1,000 2011 PPP international dollars, (4) in 1,000 square kilometers, (5) and (6) in number of species. 
Table 2: OLS regressions of $L n$ Extinction rate on $L n$ Population density and $L n$ GDP per capita.

(1)

(2)

(3)

(4)

\begin{tabular}{|c|c|c|c|c|}
\hline \multirow[t]{3}{*}{ Ln Population density } & $.132^{* * *}$ & $.134^{* * *}$ & $.134^{* * *}$ & $.114^{* * *}$ \\
\hline & $(.027)$ & $(.028)$ & $(.039)$ & $(.029)$ \\
\hline & {$[.218]$} & {$[.223]$} & & {$[.189]$} \\
\hline \multirow[t]{3}{*}{ Ln GDP per capita } & $.148^{* \star *}$ & $.172^{* \star *}$ & $.172^{* *}$ & $.171^{* \star *}$ \\
\hline & $(.049)$ & $(.050)$ & $(.075)$ & $(.049)$ \\
\hline & [.140] & [.163] & & [.162] \\
\hline \multirow[t]{3}{*}{ Ln Species assessed } & & & & $-.213^{* \star *}$ \\
\hline & & & & $(.074)$ \\
\hline & & & & {$[-.229]$} \\
\hline \multirow[t]{3}{*}{ Ln Data deficient species } & & & & $.295^{\star \star *}$ \\
\hline & & & & $(.067)$ \\
\hline & & & & {$[.356]$} \\
\hline Region type controls included & YES & YES & YES & YES \\
\hline Weather controls included & NO & YES & YES & YES \\
\hline $\begin{array}{l}\text { Standard errors clustered }(n= \\
\text { 24) }\end{array}$ & NO & NO & YES & NO \\
\hline$N$ & 508 & 508 & 508 & 508 \\
\hline $\mathrm{R}^{2}$ & .532 & .537 & .537 & .556 \\
\hline F-statistic ${ }^{a}$ & $15.00^{* \star *}$ & $15.70^{\star \star \star}$ & $15.70^{* * *}$ & $13.41^{\star \star \star}$ \\
\hline
\end{tabular}




\section{Appendix A}

Extended data description: omitted regions

The 30 regions that are excluded from the analysis are: 1 . Amsterdam and Saint-Paul Islands (59.8), 2. Antarctica (85.2), 3. Antipodean Islands (72.4), 4. Ascension Island (168.3), 5. Bouvet Island (96.2), 6. Clipperton Island (89.0), 7. Cocos Island (188.5), 8. Cocos Keeling Islands (61.2), 9. Crozet Islands (1), 10. Guadalupe Island (445.6), 11. Heard Island and McDonald Islands (237.1), 12. Johnston Atoll (36.9), 13. Kazan-retto (455.6), 14. Kerguelen Islands (38.0), 15. Kermadec Islands (117.3) 16. Macquarie Island (236.3), 17. Marcus Island (106.3), 18. Marion and Prince-Edward Islands (29.6), 19. Norfolk Island (114.6), 20. North Solomon Islands (256.6), 21. Paracel Islands (21.4), 22. Revillagigedo Islands (334.3), 23. Saba (134.8), 24. Saint Helena (665.2), 25. Savage Islands (32.1), 26. Sint Eustatius (137.2), 27. South Georgia and the South Sandwich Islands (98.2), 28. Tristan da Cunha (266.3), 29. Wake Islands (37.4), 30. Western Sahara (82.3), with Extinction rate in parentheses. These regions represent nearly $10 \%$ of the assessed land surface, mostly due to the Antarctica, and have a slightly lower average Extinction rate (mean 156.8).

\section{Extended data description: additional sources and robustness checks}

I used the World Bank (data.worldbank.org) 2015 data on population density for the 191 regions listed below, and for 168 of these regions (unless indicated otherwise in parentheses), I also used the 2015 data on GDP per capita: Afghanistan, Albania, Algeria, American Samoa (CIA 2016 GDP), Andorra (UN 2017 GDP per capita), Angola, Antigua and Barbuda, Armenia, Aruba (World Bank 2011 GDP), Austria, Azerbaijan, The Bahamas, Bahrain, Bangladesh, Barbados, Belarus, Belgium, Belize, Benin, Bermuda (World Bank 2013 GDP), Bhutan, Bolivia, Bosnia and Herzegovina, Botswana, British Virgin Islands (UN 2017 GDP), Brunei Darussalam, Bulgaria, Burkina Faso, Burundi, Cabo Verde, Cambodia, Cameroon, Cayman Islands (World Bank 2011 GDP), Central African Republic, Chad, Colombia, Comoros, Dem. Rep. Congo, Rep. Congo, Costa Rica, Cote d'Ivoire, Croatia, Cuba (UN 2017 GDP), Curacao (UN 2017 GDP), Czech Republic, Denmark, Djibouti(World Bank 2011 GDP), Dominica, Dominican Republic, Ecuador, Arab Rep. Egypt, El Salvador, Equatorial Guinea, Eritrea (World Bank 2011 GDP), Estonia, Ethiopia, Faroe Islands (CIA 2014 GDP), Fiji, Finland, France, Gabon, The Gambia, Georgia, Germany, Ghana, Greece, Greenland (UN 2017 GDP), Grenada, Guam (ClA 2015 GDP), Guatemala, Guinea, Guinea-Bissau, Guyana, Haiti, Honduras, Hong Kong, Hungary, Iceland, Islamic Rep. Iran, Iraq, Ireland, Israel, Italy, Jamaica, Jordan, Kazakhstan, Kenya, Kiribati, Dem. People's Rep. Korea (UN 2017 GDP), Rep. Korea, Kuwait, Kyrgyz Republic, Lao PDR, Latvia, Lebanon, Lesotho, Liberia, Libya, Lithuania, Luxembourg, Macao, Macedonia FYR, Madagascar, Malawi, Maldives, Mali, Malta, Marshall Islands, Mauritania, Mauritius, Micronesia Fed. States., Moldova, Mongolia, Montenegro, Morocco, Mozambique, Myanmar, Namibia, Nauru, Nepal, Netherlands, New Caledonia (UN 2017 GDP), Nicaragua, Niger, Nigeria, Northern Mariana Islands (CIA 2016 GDP), Norway, Oman, Pakistan, Palau, Panama, Papua New Guinea, Paraguay, Peninsular Malaysia, Peru, Philippines, Poland, Portugal, Puerto Rico, Qatar, Romania, Rwanda, Samoa, Saudi Arabia, Senegal, Serbia, Seychelles, Sierra Leone, Singapore, Sint Maarten (World Bank 2011 GDP), Slovak Republic, Slovenia, Solomon Islands, Somalia (UN 2017 GDP), Spain, Sri Lanka, St. Kitts and Nevis, St. Lucia, St. Martin (CIA 2005 GDP), St. Vincent and the Grenadines, Sudan, Suriname, Sweden, Switzerland, Syrian Arab Republic (UN 2017 GDP), Tajikistan, Tanzania, Thailand, Timor-Leste, Togo, Tonga, Trinidad and Tobago, Tunisia, Turkey, Turkmenistan, Turks and Caicos (UN 2017 GDP), Tuvalu, Uganda, Ukraine, United Arab Emirates, United Kingdom, Uruguay, Uzbekistan, Vanuatu, Venezuela RB (World Bank 2014 GDP), Vietnam, U.S. Virgin Islands (CIA 2016 GDP), West Bank and Gaza, Yemen Rep., Zambia, and Zimbabwe.

I used the UN (data.un.org) 2017 data on population density for 13 regions listed below and on GDP per capita for 5 of these regions, for another 5 of these regions I used the CIA World Factbook GDP per capita data (with the year of the estimate in parentheses), 
and of the remaining 3 I used Eurostat 2016 GDP per capita data (indicated with an *): Anguilla, Cook Islands, Falkland Islands (2015), French Guiana*, Guadeloupe*, Martinique, Montserrat, Niue (2003), Saint Pierre and Miquelon (2006), South Sudan, Swaziland, Tokelau (1993), and Wallis and Futuna (2004). I used population density and GDP per capita from Eurostat 2016 for an additional 9 regions, being: Åland, Azores, Baleares, Canary Islands, Corsica, Crete, Madeira, Sardinia and Sicilia.

The regional estimates for the counties listed in footnote 9 (and below) were obtained from ranked lists on Wikipedia pages that linked to the respective national statistics bureaus: For Argentinian (23 regions), population and GDP data are for 2013 and 2008 come from the Instituto Nacional de Estadística y Censos de la República; for Australia (8 regions), population density and GDP data for 2017 and 2016 come from the Australian Bureau of Statistics; for Brazil (27 regions), population and GDP data for 2014 and 2015 come from the Brazilian Institute of Geography and Statistics; for Canada (13 regions), population and GDP for 2016 come from Statistics Canada; for Chile (12 regions), population and GDP data for 2015 and 2014 come from the National Statistics Office's and the Central Bank of Chile, respectively; for China (31 regions), population and GDP data for 2016 and 2015 come from the National Bureau of Statistics of China; for India (31 regions), population and GDP data for 2011 and 2016 come from the Ministry of Statistics and Program Implementation; for Indonesia (7 regions), population and GDP data for 2017 come from Badan Pusat Statistik; for Japan (5 regions), population and GDP data for 2007 come from the Statistics Bureau of Japan; for Mexico (32 regions), population and GDP data for 2015 come from the Instituto Nacional de Estadística y Geografía; for Russia (21 regions), population and GDP data for 2018 and 2009 come from the Federal State Statistics Service and UNDP National Human Development Report for the Russian Federation, respectively; for South Africa (9 regions), population and GDP data for 2011 and 2010 come from Statistics South Africa; for United States (50 regions), population and GDP data for 2015 come from the Bureau of Economic Analysis.

Finally, for 24 regions, I either use estimates provided on the Wikipedia about the region referring to a local census, or in case I was unable to find an estimate, I used the national average. The details are available upon request, and none of the results are not sensitive to the inclusion these regions.

I also ran the regressions displayed in column (1), (2) and (4) of Table 2 using only the 213 observations with World Bank, UN, CIA World Factbook and Eurostat data, complemented with the 13 countries listed in footnote 9 instead of their regional estimated (and New Zealand, as there were 3 regions from New Zealand in the 26 unlisted regions above). For this smaller, the population density results sample are similar across the three specifications and the coefficient for GDP per capita are about half the size and only borderline significant (with p-values of .221, .072, and .113).

I could only find 2015 estimates for about half of the regions. As a robustness check, I corrected national estimates from another year by the World Bank's World average population and GDP growth rates, and similarly, corrected regional estimates from another year by their national average population and GDP growth rates according to the World Bank data. The results are robust to using these corrected population density and GDP per capita variables. 


\section{Appendix B}

Scatterplots of $L n$ Extinction rate with $L n$ Population density and Ln GDP per capita for (sub)continental and FAO marine regions.
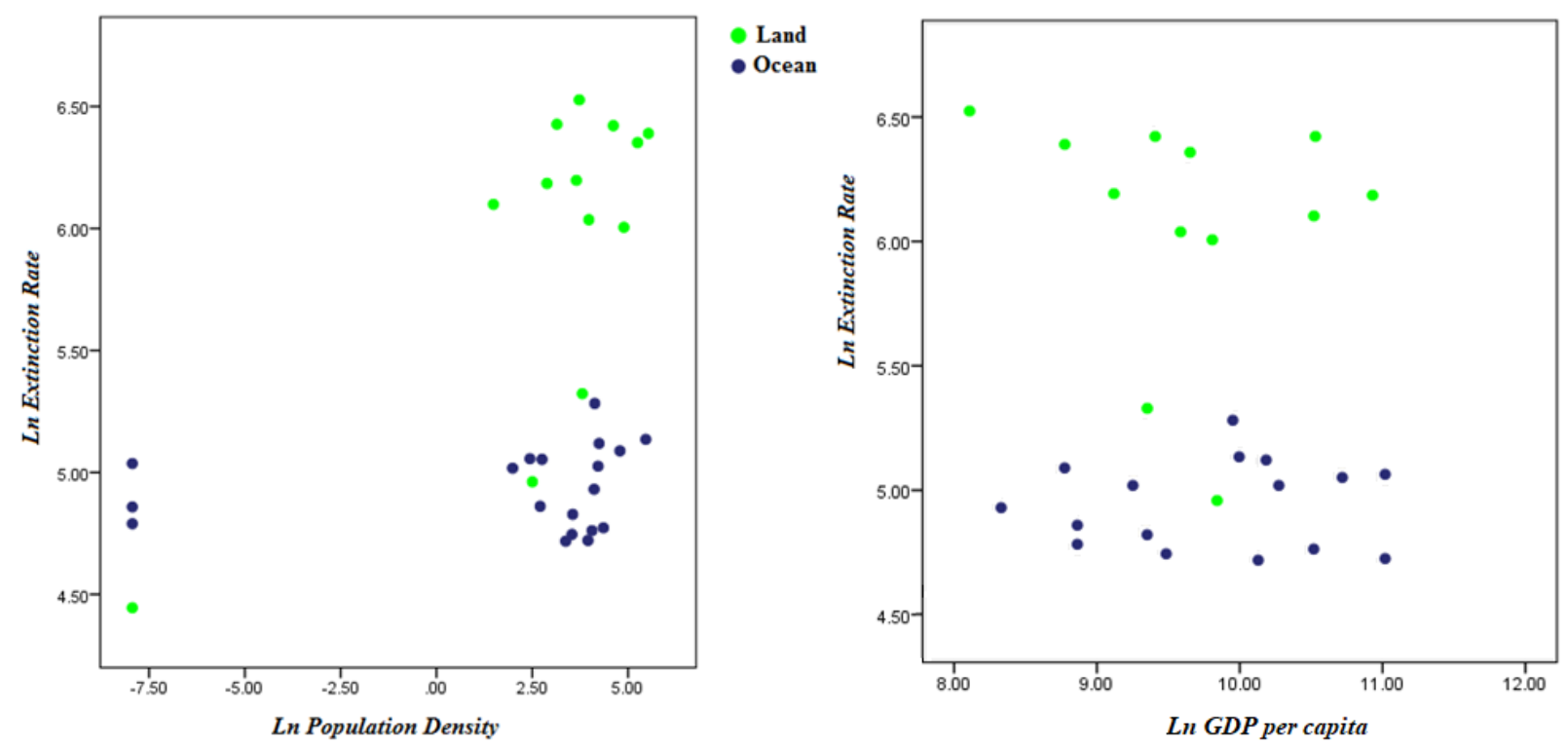

To calculate the population density for the 19 FAO Marine regions, I divided the sum of the population of all islands within and all coastal regions adjacent to the FAO region by the sum of the land surface for these regions; likewise, for the GDP per capita I divided the sum of the GDP by the sum of the population for the same regions. For the 13 (sub)continental regions, the 12 described in footnote 10 plus Antarctica, I included all landlocked regions in these sums as well. Note that, Antarctica and the 3 Antarctic oceans regions are not included in the scatterplot for GDP per capita. An OLS regression of $L n$ Extinction rate on Ln Population density, Ln Land surface, and a 'land dummy' for the (sub)continental observations, yields a standardized coefficient for population density of 0.267 ( $p$-value =.020). However, this result is sensitive to the inclusion of Antarctica and the 3 Antarctic oceans regions. Without these observations, the coefficient is almost half and no longer significant $(.140, p$-value $=.157)$. The relationship between the extinction rate and GDP per capita is not significant (and negative) at this (sub)continental level. 


\section{Appendix C}

OLS regression Ln Extinction rate on controls

\begin{tabular}{|c|c|c|c|}
\hline Dependent variable & \multicolumn{3}{|c|}{ Ln Extinction rate } \\
\hline Independent variables & (1) & $(2)$ & $(4)^{a}$ \\
\hline Ln Land surface & $\begin{array}{l}.079^{* * *} \\
(.021)\end{array}$ & $\begin{array}{l}.082^{* * *} \\
(.021)\end{array}$ & $\begin{array}{l}.104^{* *} \\
(.025)\end{array}$ \\
\hline Island & $\begin{array}{l}.536^{* *+} \\
(.138)\end{array}$ & $\begin{array}{l}.544^{x+4} \\
(.140)\end{array}$ & $\begin{array}{l}.514^{*+x} \\
(.139)\end{array}$ \\
\hline Landlocked & $\begin{array}{l}-.334^{\text {t+x }} \\
(.085)\end{array}$ & $\begin{array}{l}-.336^{* * *} \\
(.086)\end{array}$ & $\begin{array}{c}-.060 \\
(.094) \\
\end{array}$ \\
\hline Caribbean & $\begin{array}{l}-.923^{x+x} \\
(.213)\end{array}$ & $\begin{array}{c}-.947^{\text {tx+k }} \\
(.214)\end{array}$ & $\begin{array}{r}-1.272^{* * *} \\
(.239)\end{array}$ \\
\hline East Asia & $\begin{array}{l}-.516^{\text {t** }} \\
(.164)\end{array}$ & $\begin{array}{l}-.541^{\text {t+* }} \\
(.165)\end{array}$ & $\begin{array}{c}-1.049^{* *} \\
(.178)\end{array}$ \\
\hline Europe & $\begin{array}{l}-.779^{*+* x} \\
(.156)\end{array}$ & $\begin{array}{l}-.814^{\text {x+x+x}} \\
(.157)\end{array}$ & $\begin{array}{r}-1.236^{* *+} \\
(.182)\end{array}$ \\
\hline Mesoamerica & $\begin{array}{c}.113 \\
(.162)\end{array}$ & $\begin{array}{c}.098 \\
(.163)\end{array}$ & $\begin{array}{c}.085 \\
(.160) \\
\end{array}$ \\
\hline North Africa & $\begin{array}{l}-.252 \\
(.325)\end{array}$ & $\begin{array}{l}-.195 \\
(.327)\end{array}$ & $\begin{array}{l}-.622^{*} \\
(.325)\end{array}$ \\
\hline North America & $\begin{array}{l}-.945^{* * t} \\
(.139)\end{array}$ & $\begin{array}{l}-.967^{*+*} \\
(.140)\end{array}$ & $\begin{array}{r}-1.039^{*+*} \\
(.186)\end{array}$ \\
\hline North Asia & $\begin{array}{r}-3.439^{* *} \\
(.186)\end{array}$ & $\begin{array}{c}-3.442^{* * *} \\
(.187)\end{array}$ & $\begin{array}{c}-3.488^{* * *} \\
(.179)\end{array}$ \\
\hline Oceania & $\begin{array}{l}-.197 \\
(.185)\end{array}$ & $\begin{array}{c}-.228 \\
(.186)\end{array}$ & $\begin{array}{l}-.371^{*} \\
(.192)\end{array}$ \\
\hline South and Southeast Asia & $\begin{array}{c}-.211 \\
(.148)\end{array}$ & $\begin{array}{l}-.245 \\
(.152)\end{array}$ & $\begin{array}{l}-.664^{*+*} \\
(.164)\end{array}$ \\
\hline Sub-Saharan Africa & $\begin{array}{l}-.377^{*+*} \\
(.141)\end{array}$ & $\begin{array}{l}-.387^{*+*} \\
(.141)\end{array}$ & $\begin{array}{l}-.415^{* x} \\
(.160)\end{array}$ \\
\hline West and Central Asia & $\begin{array}{l}-.346^{*} \\
(.183)\end{array}$ & $\begin{array}{c}-.242 \\
(.194)\end{array}$ & $\begin{array}{l}-.583^{*+x} \\
(.209)\end{array}$ \\
\hline City & $\begin{array}{c}.076 \\
(.273)\end{array}$ & $\begin{array}{c}.072 \\
(.274)\end{array}$ & $\begin{array}{l}-.255 \\
(.269)\end{array}$ \\
\hline Desert & & $\begin{array}{l}-.305^{*} \\
(.157)\end{array}$ & $\begin{array}{l}-.252 \\
(.155)\end{array}$ \\
\hline Semi-arid & & $\begin{array}{c}-.055 \\
(.118)\end{array}$ & $\begin{array}{l}.107 \\
(.117)\end{array}$ \\
\hline Tropical & & $\begin{array}{c}-.031 \\
(.168)\end{array}$ & $\begin{array}{c}.104 \\
(.164)\end{array}$ \\
\hline $\mathrm{N}$ & 508 & 508 & 508 \\
\hline$R^{2}$ & .503 & .507 & - \\
\hline
\end{tabular}

${ }^{* * *},{ }^{* *},{ }^{*}$ indicate coefficients significantly different from zero at the $1 \%, 5 \%$, and $10 \%$, standard errors are shown in parentheses and standardized coefficients in brackets.

a. Reports the estimated coefficients for the control variables of column (4) in Table 2. 